\title{
Stigma by health and mental health professionals in comorbid states
}

\author{
Levent Küey \\ From $1^{\text {st }}$ International Congress on Neurobiology and Clinical Psychopharmacology and European \\ Psychiatric Association Conference on Treatment Guidance \\ Thessaloniki, Greece. 19-22 November 2009
}

People with mental disorders are facing the double pressure of undertreatment both for their mental and physical diseases. The dimensions and burden of these problems associated with the high rates of medical comorbidity, disability, and mortality among people with mental disorders have been revealed in many recent reviews. This issue constitutes a major public health/ mental health challenge and has serious consequences, including the stigma by health professionals. Efforts tackling the stigmatization attached to mental disorders have a history of almost couple decades. On the contrary, the stigma on the management of the somatic illnesses of patients with mental disorders is an issue that has only recently raised concern. Health/Mental health professionals can simultaneously be stigmatizers, stigma recipients and agents of de-stigmatization. The stigmatizing practices and approaches of the physicians, psychiatrists and the mental health workers on somatic illnesses and somatic treatments of patients with mental disorders is a serious aspect of the problem, and can be conceptualized as a reconstructed specific form of general stigma. The stigma by the health and mental health professionals especially on the treatment of medical comorbidities of people with mental disorders is the focus of this presentation. Hence, current researches on the relations of stigma and mental health professionals, general medical professionals, medical education, the care givers, and the cultural dimensions are reviewed. The conclusions warn us on reviewing the undergraduate and graduate training programmes in the context of current stigma theories and emphasize the need to

World Psychiatric Association, Istanbul Bilgi University, Istanbul, Turkey

BHoMed Central @ 2009 Küey; licensee BioMed Central Ltd. improve our means of reducing the stigma among the mental health workers and the physicians.

Published: 22 April 2010

doi:10.1186/1744-859X-9-S1-S41

Cite this article as: Küey: Stigma by health and mental health professionals in comorbid states. Annals of General Psychiatry 2010 9(Suppl 1):S41.
Submit your next manuscript to BioMed Central and take full advantage of:

- Convenient online submission

- Thorough peer review

- No space constraints or color figure charges

- Immediate publication on acceptance

- Inclusion in PubMed, CAS, Scopus and Google Scholar

- Research which is freely available for redistribution

Submit your manuscript at www.biomedcentral.com/submit
C Biomed Central 